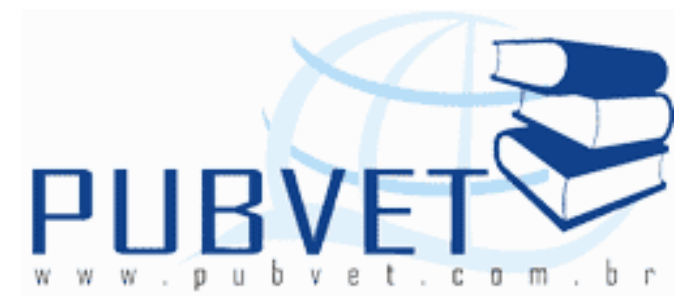

PUBVET, Publicações em Medicina Veterinária e Zootecnia.

\title{
Potencial de utilização de silagem de gramíneas tropicais não convencionais e cana-de-açúcar
}

\footnotetext{
Claudio Jonasson Mousquer ${ }^{1 *}$, Mérik Rocha Silva ${ }^{1}$, Wanderson José

Rodrigues de Castro ${ }^{1}$, Geferson Antonio Fernandes ${ }^{2}$, Fabíola Francisca Dias Fernandes ${ }^{3}$, Amorésio Souza Silva Filho ${ }^{1}$, Larissa Cardoso Feijó ${ }^{1}$, Verônica Bandeira Ferreira ${ }^{1}$
}

1 Mestrando em Ciência Animal da Universidade Federal de Mato Grosso, campus de Cuiabá-MT

${ }^{2}$ Graduando em Zootecnia da Universidade Federal de Mato Grosso, campus de Sinop-MT

${ }^{3}$ Medica Veterinária - Autônoma, Sinop-MT

* Correspondência: cjm@zootecnista.com.br

\section{Resumo}

A mais básica das formas de armazenar alimentos volumosos produzidos em quantidade suficiente no verão é a ensilagem de forrageiras produzidas de forma satisfatória. A estacionalidade de produção de plantas forrageiras não é particularidade do Brasil, vários são os países que também apresentam essa característica de distribuição sazonal de forragens durante 0 ano, principalmente devido a ocorrência de baixas temperaturas, limitando dessa forma o crescimento das plantas forrageiras. Algumas alternativas são apontadas no sentido de amenizar parte dessa situação, entre elas a 
MOUSQUER, C.J. et al. Potencial de utilização de silagem de gramíneas tropicais não convencionais e cana-de-açúcar. PUBVET, Londrina, V. 7, N. 22, Ed. 245, Art. 1622, Novembro, 2013.

intensificação de produção de volumosos suplementares durante o verão, visando a conservação de forragem para o inverno, como as gramíneas tropicais ou mesmo a condução de culturas que se disponibilizem no inverno, como a cana-de-açúcar e os seus sub-produtos. A ensilagem é um processo de conservação de forragem que tem como objetivo final preservar forragem de alto valor nutritivo com o mínimo de perdas, quando respeitado todo seu processo que vai desde a colheita e picagem até o fornecimento aos animais.

Palavras-chave: ensilagem, plantas forrageiras, alimentação, aditivo

\title{
Potential use of tropical grass silage unconventional and cane sugar
}

\begin{abstract}
The most basic way to store bulky foods produced in sufficient quantity in the summer is the ensiling forages produced satisfactorily. The seasonal production of forage plants is not particularity of Brazil, there are several countries that also feature this characteristic seasonal distribution forages during the year, mainly due to lower air temperatures, thereby limiting the growth of forage plants. Some alternatives are pointed in order to ease part of this situation, including the intensification of production bulky supplementary during the summer in order to preserve for winter of forage, such as tropical grasses or even the conduct of cultures to be available in winter such as sugar cane and its by-products. The ensiling is a conservation process of forage that has as ultimate objective to preserve forage of high nutritional value with minimal losses when respected throughout its process ranging from the harvest and chipping to the animal feeding.
\end{abstract}

Keywords: ensiling, forage plants, feeding, additive

\section{Introdução}

A produção de carne e leite no Brasil tem como base a utilização das pastagens naturais e/ou cultivadas. Isto faz com que o país possa concorrer 
MOUSQUER, C.J. et al. Potencial de utilização de silagem de gramíneas tropicais não convencionais e cana-de-açúcar. PUBVET, Londrina, V. 7, N. 22, Ed. 245, Art. 1622, Novembro, 2013.

num mercado internacional altamente competitivo, produzindo a baixos custos. Entretanto, já é bastante conhecida a sazonalidade da produção forrageira durante o ano, ocorrendo um período de abundância de forragem com bom valor nutritivo, em contraste a um período de escassez de alimento associado à redução do seu valor nutritivo (Andrade, 1995).

Os principais prejuízos causados pela estacionalidade na produção de forrageiras são relacionados ao atraso no crescimento de animais jovens, perda de peso nos machos adultos e consequentemente aumentando a idade de abate dos bovinos, atraso na idade da primeira parição e baixa fertilidade do rebanho.

Sem duvida uma das principais dificuldades da exploração intensiva de pastagens, por meio de pastejo rotacionado, na maior parte do território brasileiro, é a necessidade de ajuste da lotação das pastagens em decorrência das variações climáticas que criam, durante o ano, uma estação de alta e outra de baixa disponibilidade qualitativa e quantitativa de forragem. Para reduzir as perdas de forragem e o acúmulo de resíduo pós-pastejo, que prejudicam a qualidade da dieta do animal e da rebrota da planta, uma alternativa seria conservar parte e/ou o excesso da forragem produzida no período de maior crescimento das forrageiras na forma de silagem.

Quando se trata de produção animal, é necessário se ter em vista a adequação correta da alimentação num determinado ramo de produção. Tanto na reprodução, como na produção de corte e na produção de leite, o ideal é identificar as necessidades nutricionais do animal, para assim escolher um regime alimentar adequado. Sendo a análise de alimentos um parâmetro para se estimar a qualidade do alimento, para assim chegar o mais próximo do desempenho animal desejado.

Uma alternativa de volumoso suplementar para o período seco do ano é a utilização de silagem, embora existam várias plantas forrageiras com potencial de uso, envolvendo as anuais e perenes, o milho merece destaque pois apresenta composição da planta que resulta em ótima fermentação no 
MOUSQUER, C.J. et al. Potencial de utilização de silagem de gramíneas tropicais não convencionais e cana-de-açúcar. PUBVET, Londrina, V. 7, N. 22, Ed. 245, Art. 1622, Novembro, 2013.

silo, associado ao elevado valor nutritivo da silagem produzida (Cruz e Pereira Filho, 2001). A utilização de forrageiras conservadas, principalmente na forma de silagem, é uma alternativa viável para que se possa garantir o fornecimento de forragem de alta qualidade durante o período de escassez de alimentos (Silva et al, 2005).

Como uma alternativa ao milho tem-se o capim-elefante, cujo seu rendimento por área é elevado, reduzindo os custos de produção de matéria seca por hectare. Porém a ensilagem de capins apresenta como principais obstáculos o elevado teor de umidade da planta e o reduzido teor de carboidratos solúveis, resultando em elevadas perdas de massa associada a uma silagem de qualidade questionável, uma vez que a produção de silagem é um processo de custo elevado, em que o efetivo controle é fundamental para ser bem sucedido.

Além disso, a administração da produção de forragem, o uso de máquinas e equipamentos adequados, associado a informações relativas à época de corte, tamanho de partícula, duração da ensilagem, vedação do silo e manejo do silo após sua abertura, são fatores que se não forem implementados corretamente podem causar sérias perdas quantitativas e qualitativas na silagem, com consequente perdas econômicas relativas ao desempenho animal (Ferreira, 2001).

A cana-de-açúcar (Saccharum officinarum, L.) é uma planta de grande importância para a economia brasileira, já que devido à sua industrialização em açúcar e álcool se torna uma grande geradora de empregos e energia (Nussio, 1993).

Quando realizada a ensilagem da cana-de-açúcar, os gastos com mãode-obra concentram-se em apenas um período, o que aumenta as vantagens dessa cultura em relação às outras utilizadas para a ensilagem, as quais são colhidas no período chuvoso. Além disso, o ponto de corte da cana ocorre justamente no período seco do ano, o que facilita todo o processo de ensilagem, muitas vezes prejudicado pelas chuvas (Lopes et al., 2007). A 
MOUSQUER, C.J. et al. Potencial de utilização de silagem de gramíneas tropicais não convencionais e cana-de-açúcar. PUBVET, Londrina, V. 7, N. 22, Ed. 245, Art. 1622, Novembro, 2013.

aplicação de aditivos como a uréia pode melhorar a qualidade de silagens de cana-de-açúcar e diminuir a população de leveduras e mofos, reduzindo a produção de etanol, as perdas de MS e de carboidratos solúveis e também proporcionando melhor composição bromatológica em silagens tratadas, em comparação a silagens exclusivamente de cana (Alli et al., 1983), citado por Lopes et al. (2007).

Embora a silagem de milho, a silagem de capim-elefante e a cana-deaçúcar sejam volumosos de elevado potencial de uso na alimentação de bovinos e, por esse motivo sejam os mais utilizados, apresentam limitações relativas à composição químicobromatológica, ao consumo e à digestibilidade, tornando necessária à sua utilização associada a rações concentradas no sentido de otimizar a produção de leite e de carne. Entretanto, o uso de concentrados na dieta de bovinos pode afetar de forma significativa o custo de produção, assim como a produção e a qualidade do leite e da carne além da saúde do animal (Oliveira, 2007).

A uréia dentro do silo, em decorrência da ação da urease, é convertida a amônia, que, ao se ligar à água, forma o hidróxido de amônia, capaz de solubilizar os componentes da parede celular, principalmente a hemicelulose, reduzindo a FDN (Fibra Detergente Neutro) do material (Reis et al., 1990), o que reflete positivamente na digestibilidade dos constituintes celulares (Sundstol et al., 1982).

\section{Silagem}

A silagem consiste da forragem conservada em recipiente denominado silo, a partir do processo de ensilagem, por intermédio da ação de ácidos orgânicos decorrente da fermentação em condições anaeróbicas (ausência de ar) dos carboidratos solúveis da forrageira. As bactérias anaeróbias presentes nas plantas transformam os carboidratos solúveis em ácido lático e, em menor proporção o ácido acético. A presença desses ácidos reduz o pH do meio, promovendo a estabilização do processo, inibindo a deterioração. Para 
MOUSQUER, C.J. et al. Potencial de utilização de silagem de gramíneas tropicais não convencionais e cana-de-açúcar. PUBVET, Londrina, V. 7, N. 22, Ed. 245, Art. 1622, Novembro, 2013.

conseguir uma boa fermentação e assim conservar a qualidade original da forragem faz-se necessária utilização de técnicas apropriadas de ensilagem (Oliveira, 2001). A escolha do tipo de volumoso a ser utilizado deve levar em consideração aspectos técnicos e econômicos, não basta apenas tomar as devidas precauções no momento de ensilar. Para que a silagem chegue com a mesma qualidade ao cocho dos animais é fundamental estar atento a algumas estratégias importantes após a abertura do silo.

\section{Ensilagem}

Consiste na preservação de forragens úmidas, recém-colhidas, com elevado valor nutritivo, para serem administradas nas épocas de escassez de alimentos. Como já citado anteriormente, o Brasil se caracteriza por uma forte sazonalidade climática e apresenta basicamente duas épocas distintas, uma de elevada e uma de reduzida precipitação pluviométrica. As gramíneas de clima tropical utilizada nas pastagens brasileiras perdem sua qualidade e produzem muito menos nas épocas de déficit hídrico e de baixas temperaturas. Todos estes fatores justificam o emprego da técnica de ensilagem (Santos, 2006).

Quando tratamos de ensilagem de gramíneas tropicais fatores como perdas da qualidade e quantidade durante esse processo, pode tornar inviável economicamente e não ocorrendo alguns resultados esperados.

O processo de ensilagem não melhora a qualidade da forrageira, sendo o valor alimentício da silagem resultante do valor nutritivo da forragem ensilada, do processo de fermentação dentro do silo e do manejo pós-abertura do silo (Oliveira, 2007).

\section{Fatores Determinantes para Qualidade da Ensilagem}

Alguns fatores são determinantes para a qualidade da ensilagem. Após os processos de picagem da forragem para ensilar, etapas como compactação e vedação no silo vão dar as características (boa ou ruim) da silagem, para posterior fornecimento ao animal no cocho. 
MOUSQUER, C.J. et al. Potencial de utilização de silagem de gramíneas tropicais não convencionais e cana-de-açúcar. PUBVET, Londrina, V. 7, N. 22, Ed. 245, Art. 1622, Novembro, 2013.

Quando se coloca a forragem no interior do silo e procede-se a compactação, elimina-se grande parte do oxigênio existente entre as partículas de forragem. Após a correta vedação do silo, os microrganismos aeróbios (necessitam de oxigênio para sobreviverem) que acompanham a forrageira, eles se encarregam de consumir o restante do oxigênio. Com o término do oxigênio, a condição no interior do silo se torna anaeróbia (sem oxigênio). Nesta condição, os microrganismos que necessitam de oxigênio para sobreviverem (aeróbios) morrem ou se tornam inativos e começa o desenvolvimento de outra classe de microrganismos, os anaeróbios (Lima e Cunha, 2006).

Os microrganismos (anaeróbios) utilizam os açúcares da forragem para produzirem alguns ácidos orgânicos que são responsáveis pela conservação da forragem na forma de silagem. E se não houver entrada de ar e, ou água no interior do silo, a silagem poderá ser armazenada por longo período. No entanto, após a abertura do silo, a silagem ficará exposta ao ar e, nesta condição, os microrganismos aeróbios (aqueles que necessitam de oxigênio para sobreviverem) voltam a atuar. Esses microrganismos são prejudiciais à qualidade da silagem, pois são agentes responsáveis pela degradação da proteína e transformam o ácido lático (fundamental para preservação da silagem) em ácido butírico. A presença de ácido butírico na silagem é indicativa de fermentação inadequada, ou seja, é indicativa de perda do valor nutritivo da silagem (Lima e Cunha, 2006).

\section{Microbiota da Silagem}

A Microbiota da silagem pode ser dividida, basicamente, em dois grupos, que são os microrganismos desejáveis e os indesejáveis. Os microrganismos desejáveis são, sobretudo, as bactérias do ácido lático (BAL), que fazem parte da microbiota epifítica da planta ou são adicionadas as silagens por meio de inoculantes. Os indesejáveis já são aqueles microrganismos que podem causar deterioração anaeróbica (como Clostridios) ou deterioração aeróbica (como 
MOUSQUER, C.J. et al. Potencial de utilização de silagem de gramíneas tropicais não convencionais e cana-de-açúcar. PUBVET, Londrina, V. 7, N. 22, Ed. 245, Art. 1622, Novembro, 2013.

Leveduras, Bacilos, Listeria e Mofos). Esses microrganismos podem estar presentes na cultura ou serem oriundos da contaminação, principalmente do solo, competindo com as BAL por carboidratos solúveis (CS) e seus produtos finais; em geral acabam não tendo influencia na preservação (Ávila, 2007).

-Microbiota Epifítica: É a população de microrganismos presente na forragem fresca. Essa população é muito variável e é afetada por características de espécies forrageiras, incluindo teor de açúcar, teor de matéria seca (MS), composição do açúcar, estádio de maturidade, e também características como clima, corte, secagem e processos de picagem. As BAL fazem parte da microbiota presente no material vegetal. Essa população em geral é inicialmente baixa, aumentando substancialmente entre a colheita e a ensilagem.

Ao contrario das BAL, as populações de bactérias aeróbicas e fungos filamentosos tendem a diminuir com o estabelecimento das condições anaeróbicas e abaixamento do $\mathrm{pH}$ dentro do silo.

-Bactérias ácido láticas (BAL): Microrganismo desejável. É o principal grupo de microrganismo que atua no processo fermentativo para a conservação da massa ensilada. Dentre as BAL, as mais importantes envolvidas com 0 processo fermentativo da silagem são as do gênero Lactobacillus, Streptoccocus, Pediococcus, Enteroccocus, Lactoccocus, e Leuconostoc. São bactérias gram positivas, usualmente não moveis e não esporulante.

-Clostrídios: Microrganismo indesejável. São bactérias anaeróbicas formadoras de endósporos, podendo ter um pronunciado efeito sobre a qualidade da silagem (Ávila, 2007), assim, essas bactérias causam uma fermentação secundária, que convertem ácido lático a ácido butírico, e degradam aminoácidos a aminas e amônias. Os clostrídios normalmente não são ativos na presença de oxigênio e requerem condições úmidas para crescer, 
MOUSQUER, C.J. et al. Potencial de utilização de silagem de gramíneas tropicais não convencionais e cana-de-açúcar. PUBVET, Londrina, V. 7, N. 22, Ed. 245, Art. 1622, Novembro, 2013.

sendo crescimento clostrideal raro em culturas ensiladas com menos de $65 \%$ de umidade.

Devido ao fato de os esporos de clostridios poderem sobreviver a passagem através do trato digestivo de vacas leiteiras, estes podem ser transferidos da silagem para o leite via fezes ou contaminação fecal pelo úbere. Assim, os prejuízos da fermentação clostrideal nas silagens vão além da qualidade do leite e seus derivados.

Clostrideos formam esporos que constituem um importante critério de qualidade higiênica das silagens com relação a produção de leite, cuja classificação pode ser adequado ou não á produção de queijos (Danner et al., 2003).

-Enterobacteriáceas: Microrganismo indesejável. As enterobactérias são bacilos gram-negativos e anaeróbicos facultativos; a maioria é não patogênica, porem existe um numero considerável de patógenos que podem ser prejudiciais a homens, animais e plantas (Ávila, 2007).

Essas bactérias competem com as BAL pelos açúcares no inicio do processo fermentativo da massa ensilada. Elas também fermentam açúcares e produzem ácido lático, acético e etanol como as BAL, mas o principal produto é o acido acético, que reduz a taxa de declínio do pH no material ensilado e aumenta as perdas de MS durante a fase de fermentação e são capazes de degradar proteínas. Esta degradação de proteínas não somente causa redução do valor nutritivo, mas também resulta na produção de compostos tóxicos como aminas biogênicas e ácidos graxos ramificados.

-Listéria: Microrganismo indesejável. São bactérias aeróbios ou anaeróbios facultativos. A espécie $L$. monocytogenes, que é anaeróbica facultativa, é uma das espécies mais importantes no processo de ensilagem por ser patogênica a vários animais e ao homem. Animais com o sistema imunológico enfraquecido 
MOUSQUER, C.J. et al. Potencial de utilização de silagem de gramíneas tropicais não convencionais e cana-de-açúcar. PUBVET, Londrina, V. 7, N. 22, Ed. 245, Art. 1622, Novembro, 2013.

(como fêmeas gestantes ou recém nascidos) são mais susceptíveis a infecções causada por L. monocytogenes (Ávila, 2007).

-Bacilos: Microrganismo indesejável. Como os clostrideos são bactérias formadoras de endósporos, podendo ser facilmente distinguidos dos clostrideos por serem aeróbicos facultativos, enquanto todos os clostrideos são anaeróbicos obrigatórios. A proliferação de bacilos na silagem é indesejável, não somente por que são menos eficientes produtores de acido lático e acético do que as $B A L$, mas porque aumentam a deterioração aeróbica da silagem nos últimos estágios (Ávila, 2007).

-Fungos filamentosos e leveduras: Microrganismo indesejável. Ensilagem de culturas forrageiras com alto teor de MS, compactação inadequada e baixas taxas de fermentação são fatores que favorecem o surgimento de leveduras e fungos filamentosos no silo. Isso ocorre porque esses fatores permitem a entrada de ar dentro do silo possibilitando, assim, o desenvolvimento desses microrganismos e consequentemente, reduzindo a aceitabilidade e contaminando a silagem com micotoxinas (Ávila, 2007).

Muitas espécies de leveduras degradam o ácido lático, causando um aumento de $\mathrm{pH}$ da silagem e promovendo, assim, condições para que outros microrganismos deterioradores se desenvolvam.

\section{Fases dos Processos de Ensilagem}

-Fase aeróbica: ocorre durante o enchimento e se prolonga até poucas horas depois do fechamento do silo. A elevada concentração de $\mathrm{O} 2$ favorece $\mathrm{O}$ crescimento de microorganismos aeróbicos, como fungos, leveduras e algumas bactérias. A atuação destes microorganismos, juntamente com o processo respiratório da planta, promove redução do $\mathrm{O} 2$ e dá início a segunda fase. 
-Fase de fermentação ativa: nesta fase há uma queda acentuada do $\mathrm{pH}$ da silagem devido à formação de ácidos orgânicos, a partir de açúcares. Inicialmente, atuam enterobactérias (produtoras de ácido acético) e bactérias heterofermentativas, posteriormente, tornam-se dominantes as homofermentativas (produtoras de ácido lático). Entretanto, o acido que deve estar em maior proporção numa silagem é o lático, devido à sua maior acidez, eficiência em baixar $\mathrm{o} \mathrm{pH}$ rapidamente, e capacidade para manter a estabilidade da silagem, tanto na fase anaeróbica com na aeróbica (após a abertura do silo). Esta fase se prolonga até que o $\mathrm{pH}$ caia para valores abaixo de 5,0 .

-Fase de estabilidade: $\mathrm{O}$ pH ácido da silagem $(3,8$ á 5,0$)$ e a condição de anaerobiose conservam a mesma até o momento da abertura do silo. Nesta fase, somente as bactérias ácidas lácticas se encontram em atividade, porém muito reduzida.

Pra ser determinante nas silagens de boa qualidade, o acido lático é o que tem que aparece em maior proporção (normalmente $60 \%$ dos ácidos orgânicos totais) e é praticamente sem odor. O cheiro de vinagre em algumas silagens é devido à presença do acido acético. Quanto mais intenso esse cheiro, mais tempo a silagem demorou em baixar $\mathrm{o} \mathrm{pH}$, que pode ser decorrente da baixa disponibilidade de CS (carboidratos solúveis) no início dessa fase.

-Fase de descarga: ocorre por ocasião da abertura do silo, e a exposição de levadas concentrações de 02 , normalmente favorece o crescimento de fungos e leveduras. É chamada de estabilidade aeróbica, a propriedade de inibição da proliferação de fungos e leveduras, após o contato com o $\mathrm{O} 2$. 
MOUSQUER, C.J. et al. Potencial de utilização de silagem de gramíneas tropicais não convencionais e cana-de-açúcar. PUBVET, Londrina, V. 7, N. 22, Ed. 245, Art. 1622, Novembro, 2013.

\section{Processo de Picagem da Forragem e Máquinas para seu uso}

A picagem e o condicionamento mecânico pode melhorar o processo de conservação da silagem, permitindo melhor acomodação do material dentro do silo, diminuindo a fase aeróbica do processo de ensilagem.

A colheita de plantas para ensilagem no ótimo estádio de maturidade, para máximo rendimento de nutrientes digestíveis, necessariamente não resulta em elevados consumos de forragem e altas taxas de desempenho animal, dado que o processo de ensilagem resulta em perdas na colheita e no armazenamento, bem como no consumo potencial da forragem ensilada, em comparação ao mesmo material, na forma fresca (Resende et al, 2005). Os cortes deverão ser feitos antes da florada e quando a planta apresenta alta presença de folhas verdes, devendo coincidir como teor de matéria seca (MS) próximo ou superior a $25 \%$ no momento do corte.

As maiores reduções no consumo de silagem estão associadas com aquelas forrageiras de alta umidade ou colhidas diretamente, sem présecagem prévia. Estas silagens sofrem fermentação mais intensa, resultando em maiores perdas e aumentos na produção de ácidos acético e butírico (Resende et al, 2005).

A disponibilidade de novas máquinas especializadas no mercado tem proporcionado maior eficiência nas operações de ensilagem, com conseqüente maior probabilidade de sucesso no emprego dessa tecnologia. Isso porque a partir da década de 90 empresas nacionais começaram a desenvolver modelos de equipamentos que possibilitaram a implementação dessa tecnologia (Bumbieris Junior, 2006).

De maneira geral, observa-se que as máquinas nacionais utilizadas para essa finalidade ainda são pouco eficientes, apresentando baixos rendimentos de corte, necessidade frequente de manutenção e, principalmente, o tamanho de corte das partículas não é adequado para o adequado consumo, metabolismo e, consequentemente, desempenho animal. 
Nos últimos anos, embora ainda de forma incipiente, tem havido grande preocupação das indústrias na melhoria do desempenho das forrageiras utilizadas para o corte e colheita. Porém, um aspecto que deve ser lembrado, é que não existe tendência de correlação entre a melhoria no desempenho das máquinas e as exigências dos animais, no sentido de um alimento com tamanho de corte menor. O direcionamento dado pela indústria diz respeito à melhoria na eficiência de corte, traduzida por maior volume de forragem por unidade de tempo de trabalho (toneladas/hora) e, não necessariamente na redução do tamanho de partículas, sendo esse o grande desafio à ser superado (Resende et al, 2005).

\section{Tamanho das Particulas, Enchimento e Compactação da Silagem no Silo}

O processamento físico, por meio da picagem e esmagamento pode melhorar o processo de conservação da silagem, permitindo melhorar a acomodação do material dentro do silo e diminuir a fase aeróbica (Igarasi, 2002). O tamanho da partícula e a compactação do material no silo influenciam diretamente a qualidade da fermentação, pois um material com tamanho ideal de partículas e bem compactado resulta em um ambiente anaeróbico, fundamental para o desenvolvimento de bactérias ácido láticas (Santos et al, 2006).

O enchimento do silo deve ser feito o mais rápido possível e o tempo não deve estar chuvoso para iniciar os trabalhos de ensilagem e, após iniciado, não pode ser interrompido por muito tempo. Havendo interrupção, deve-se proceder fechamento parcial do silo.

A compactação é fundamental para a qualidade final que, ao expulsar o ar presente entre as partículas da forragem, ela minimiza as perdas por respiração, melhora a estabilidade aeróbica da silagem e aumenta a capacidade de estocagem do silo. Resumindo; guarda-se mais matéria seca por metro cúbico de silo. 
MOUSQUER, C.J. et al. Potencial de utilização de silagem de gramíneas tropicais não convencionais e cana-de-açúcar. PUBVET, Londrina, V. 7, N. 22, Ed. 245, Art. 1622, Novembro, 2013.

\section{Fechamento do Silo e Retirada da Silagem}

Após o enchimento total do silo e todo processo de compactação, devese cobri-lo com lona preta e jogar uma camada fina de terra ou uma camada fina do próprio material ensilado, para melhorar a compactação com a expulsão do ar da superfície e evitar que a lona seja retirada de cima do silo com o vento, obtendo o máximo possível de conservação e consequente qualidade do material ensilado.

Para que seja possível adotar o manejo correto de retirada de silagem, o dimensionamento do silo deve ser compatível com o tamanho do rebanho. É preferível construir maior número de silos, com menores dimensões, ou silos compridos e estreitos. Assim, a área de exposição da silagem ao ar será menor e haverá rápida progressão na retirada da silagem, sendo que essa prática ocorrerá de forma mais rápida que a entrada de ar no interior do silo (Lima e Cunha, 2006).

A camada de silagem a ser retirada do silo, diariamente, não deve ser inferior a $20 \mathrm{~cm}$. Deve-se retirar a silagem de forma que o silo seja mantido liso, ou seja, não devem ser escavados 'buracos' ou 'escadas ' na silagem.

As práticas de algumas estratégias básicas no manejo do silo certamente evitará perdas e prejuízos desnecessários. Cuidados como; zelo e capricho na retirada e utilização da silagem são de fundamental importância. Sendo assim, após a abertura do silo, diariamente, deve-se descartar as partes estragadas (escuras, podres) e as partes com presença de mofo (fungadas). Silagens com essas características possuem elementos tóxicos que poderão causar sérios problemas à saúde dos animais, podendo levar até a morte.

\section{Tipos de Silos}

Segundo a Embrapa gado de corte, os silos mais freqüentemente utilizados são os horizontais, do tipo trincheira ou de superfície. Há também silos cilíndricos verticais, do tipo cisterna ou aéreo, mas são menos usados porque são de lida mais difícil. Os silos devem ser construídos próximos do 
MOUSQUER, C.J. et al. Potencial de utilização de silagem de gramíneas tropicais não convencionais e cana-de-açúcar. PUBVET, Londrina, V. 7, N. 22, Ed. 245, Art. 1622, Novembro, 2013.

local onde serão alimentados os bovinos, evitando-se assim trabalho e custo com o transporte diário de silagem.

-Silo cilíndrico de meia encosta: É construído junto a encostas para facilitar o trabalho

de carregamento, e possui cobertura de telhas. A compactação da silagem nesse tipo de silo só é possível com a utilização de homens. Embora o carregamento fique facilitado, o acesso à parte de cima do silo pode ser difícil. A retirada da silagem, porém, é mais trabalhosa. A colocação de janelas ao longo da parede do silo não só facilita a descarga (a silagem é retirada pela janela imediatamente acima do nível da silagem) como também melhora as condições para os trabalhadores durante a compactação e a retirada da silagem.

\section{-A seção ou área do corte transversal desses silos é calculada pela fórmula:}

- $\mathrm{p} \times \mathrm{r}^{2}$, onde $\mathrm{p}=$ constante 3,14 , e $\mathrm{r}=$ raio do círculo em metros.

Para conhecer o volume de um silo de meia encosta de seção cilíndrica basta multiplicar sua altura (em metros) pela sua seção $\left(e m \mathrm{~m}^{2}\right)$. Um silo com 9 metros de altura e 2 metros de raio tem:

- Área $=3,14 \mathrm{~m} \times 2^{2} \mathrm{~m}=3,14 \times 4=12,56 \mathrm{~m}^{2}$

- Altura $=9 \mathrm{~m}$

- Volume $=9 \mathrm{~m} \times 12,56 \mathrm{~m}^{2}=113,04 \mathrm{~m}^{3}$

Para se conhecer a tonelagem aproximada desse silo basta saber que cada metro cúbico (m3) de um silo como esse comporta aproximadamente $600 \mathrm{~kg}$ de silagem. A capacidade é, então:

- $113,04 \times 600 \mathrm{~kg}=68$ toneladas.

-Silo cilíndrico tipo cisterna: As vantagens desse tipo de silo são a facilidade de acesso para carregá-lo uma vez que não há subidas para se chegar à boca 
MOUSQUER, C.J. et al. Potencial de utilização de silagem de gramíneas tropicais não convencionais e cana-de-açúcar. PUBVET, Londrina, V. 7, N. 22, Ed. 245, Art. 1622, Novembro, 2013.

do silo, e a possibilidade de localizá-lo bem próximo ao estábulo. Seu carregamento é muito fácil e a maneira de fazer a compactação é idêntica à do tipo meia encosta ou aéreo. Seu descarregamento, porém, é o mais difícil pois exige dois homens trabalhando (um dentro do silo e outro fora) e um sistema de balaios, cordas e roldanas. Ao se construir um silo como este deve-se incluir um telhado para evitar água de chuvas. O cálculo da área de sua seção e de sua capacidade são iguais ao do silo cilíndrico de meia encosta.

-Silo tipo trincheira ou horizontal: É o tipo mais comum hoje em dia devido ao seu baixo custo de construção e facilidades de carregamento, compactação e descarregamento. As paredes laterais devem ter $25 \%$ de declividade a partir da vertical.

-Sua seção de forma trapezoidal e sua área pode ser calculada pela fórmula:

$$
\underline{S}=[(B-b) / 2] \times h
$$

Onde: $\mathrm{B}=$ base maior em metros

$\mathrm{b}=$ base menor em metros

$\mathrm{h}=$ altura do silo em metros

Para conhecer o volume de um silo tipo trincheira basta multiplicar seu comprimento (em metros) pela sua seção $\left(e m \mathrm{~m}^{2}\right.$ ). Um silo com 4 metros de base menor, 5 metros de base maior, 2 metros de altura e 18 metros de comprimento tem:

- Área $=[(4 \mathrm{~m}+5 \mathrm{~m}) / 2] \times 2 \mathrm{~m}=4,5 \mathrm{~m} \times 2 \mathrm{~m}=9 \mathrm{~m}^{2}$

- Comprimento $=18 \mathrm{~m}$

- Volume $=9 \mathrm{~m}^{2} \times 18 \mathrm{~m}=162 \mathrm{~m}^{3}$ 
MOUSQUER, C.J. et al. Potencial de utilização de silagem de gramíneas tropicais não convencionais e cana-de-açúcar. PUBVET, Londrina, V. 7, N. 22, Ed. 245, Art. 1622, Novembro, 2013.

Para se conhecer a tonelagem aproximada desse silo basta saber que cada metro cúbico de um silo tipo trincheira comporta aproximadamente $500 \mathrm{~kg}$ de silagem. A capacidade é, então:

- $162 \times 500 \mathrm{~kg}=81$ toneladas.

-Silo Superfície: É o mais barato de se construir pois não exige estruturas de alvenaria ou de revestimentos. Não tem uma seção bem definida mas se assemelha à trapezoidal. Para fazer esse silo o material deve ser amontoado e compactado sobre o solo e coberto por lona plástica segura por terra. A sua seção, quando se aproxima do tipo trapezoidal, pode ser calculada pela mesma fórmula usada para os silos tipo trincheira. O cálculo do seu volume é também feito de maneira idêntica ao dos silos trincheiras.

Para se conhecer a tonelagem aproximada desse silo basta saber que cada metro cúbico de um silo de superfície comporta aproximadamente $400 \mathrm{~kg}$ de silagem.

\section{Silagem de Gramíneas Tropicais não Convencionas}

Os capins cultivados nas condições de clima tropical apresentam elevada produção nas épocas favoráveis e redução acentuada nas épocas desfavoráveis. Normalmente observa-se um excedente de forragem nas épocas das águas, que deveria ser conservado, para posterior fornecimento nas épocas mais secas do ano. Neste contexto, a ensilagem do excedente de capins pode ser um bom expediente para aumentar a oferta de matéria seca aos animais nas ocasiões desfavoráveis. Porem, capins possuem um baixo teor de matéria seca e carboidratos solúveis, bem como um reduzido número de bactérias endógenas, de modo que sua utilização requer o emprego de técnicas que possibilitem o aumento do teor de matéria seca e o favorecimento das bactérias ácido láticas (Santos et al., 2006).

Entre as gramíneas tropicais merece destaque o Pennisetum purpureum Schum, suas variedades e seus híbridos, pelo seu potencial de produção por 
MOUSQUER, C.J. et al. Potencial de utilização de silagem de gramíneas tropicais não convencionais e cana-de-açúcar. PUBVET, Londrina, V. 7, N. 22, Ed. 245, Art. 1622, Novembro, 2013.

área, o que o diferencia de outras espécies, seja para corte e fornecimento direto, seja para a produção de silagem devido a certas particularidades como a alta produção por hectares.

Tabela 2 - Produção de matéria seca de seis gramíneas tropicais.

Espécie Forrageira

Pennisetum purpureum

Panicum maximum

Brachiaria brizantha

Brachiaria decumbens

Brachiaria ruziziensis

Cynodonn lemfluenis

Produção Média hectare por ano

50

25,8

26,5

20,3

33,5

28,3

No que se refere aos carboidratos solúveis em água, tem sido enfatizado que as gramíneas tropicais possuem teores baixos, os quais seriam insuficientes para confeç̧ão de silagens láticas. Estes valores devem ser superiores a $16 \%$ na matéria seca ou $>4 \%$ na matéria verde. Por outro lado, a disponibilidade de carboidratos não estruturais e solúveis em água, de uma forragem depende da espécie forrageira, sua relação caule/folha, estádio de maturidade, densidade do plantio, fertilização nitrogenada, etc.

Mesmo em gramíneas que possuem alto potencial de produção de matéria seca, fatores climáticos fazem com que a distribuição desta produção seja irregular, podendo resultar em substanciais perdas por excesso de produção no período de chuvas ou déficit no período seco do ano.

\section{- Pennisetum purpureum Schum - capim-elefante:}

A espécie é perene, possui crescimento cespitoso, colmos eretos e cilíndricos, folhas compridas (30-120 cm) e largas (2 a $4 \mathrm{~cm})$, inflorescência primária terminal do tipo panícula e perfilhos basais e aéreos. Apresenta diversas variedades ou cultivares que, em geral, se diferenciam por caracteres 
MOUSQUER, C.J. et al. Potencial de utilização de silagem de gramíneas tropicais não convencionais e cana-de-açúcar. PUBVET, Londrina, V. 7, N. 22, Ed. 245, Art. 1622, Novembro, 2013.

agronômicos (Nascimento Júnior, 1975; Alcântara e Bufarah, 1986; Diz, 1994; Rezende, 2005).

O capim-elefante (Pennisetum purpureum Schum) é originário do continente Africano, mais especificamente da África Tropical, e foi introduzido no Brasil em 1920, vindo de Cuba. Atualmente, encontra-se difundido nas cinco regiões brasileiras (Lopes, 2004). A conservação da forragem do capimelefante (Pennisetum purpureum Schum.) produzida na estação chuvosa é uma alternativa cada vez mais utilizada para suprir a escassez de volumoso na época seca, uma vez que esse capim apresenta alta produção de matéria seca (MS) e bom valor nutritivo (Andrade et al, 2010).

O capim-elefante é estudado há muitas décadas, mas os produtores e técnicos ainda veem a necessidade de se obter uma silagem melhor desta forrageira, visto que seu elevado teor de umidade conduz a perdas na ensilagem. As perdas por efluente reduzem o valor nutricional da silagem, pois na solução existem nutrientes, como carboidratos solúveis, ácidos orgânicos, minerais e compostos nitrogenados solúveis, o que leva a maior proporção dos componentes da parede celular na silagem, que são nutricionalmente menos desejáveis (Faria et al, 2010).

Guim et al. (2002) Considerando que grande parte da produção anual das forrageiras concentra-se na época de chuvas e que o crescimento acumulado reduz o valor nutritivo, a ensilagem constitui um dos principais métodos de conservação dessa gramínea, já que sua utilização para pastejo ou para corte na seca apresenta limitações qualitativas e quantitativas.

No intuito de reduzir as perdas na ensilagem de capim-elefante, uma das principais alternativas tem sido aumentar o teor de MS, por meio da adição de materiais absorventes, o que favorece a redução das perdas, além de contribuir para o incremento da composição química da silagem (Andrade et al, 2010).

As principais limitações à ensilagem das cultivares do capim-elefante são o alto teor de umidade, baixo teor de carboidratos solúveis e de proteína 
MOUSQUER, C.J. et al. Potencial de utilização de silagem de gramíneas tropicais não convencionais e cana-de-açúcar. PUBVET, Londrina, V. 7, N. 22, Ed. 245, Art. 1622, Novembro, 2013.

bruta, necessitando da adição de subprodutos disponível em determinada região do pais.

Os aditivos mais utilizados na ensilagem do capim-elefante são os materiais secos que elevam o teor de MS da silagem e aumentam as chances de obter fermentação adequada.

O elevado teor de umidade da forrageira pode ser reduzido pela prática do pré-murchamento, que é indicado como um dos métodos mais eficientes tanto do ponto de vista técnico quanto econômico, no sentido de se elevar o teor de MS das forragens a serem ensiladas. Nesse sentido, recomenda-se cortar o capim e deixá-lo exposto ao sol por um período de quatro a oito horas para posterior trituração. Essa prática é realizada com o objetivo de reduzir a ocorrência de fermentações secundárias (Lima e Evangelista, 2007).

Como conceito geral, tem-se que, reduzindo a umidade das plantas forrageiras, através do murchamento, obtém-se aumentos na eficiência de preservação da silagem, uma vez que com essa prática consegue-se diminuir os níveis de agua e obtendo uma boa compactação no silo posteriormente, trazemos o mais perto possível para níveis ótimos da qualidade do produto final (silagem).

O plantio do capim-elefante tem como vantagens ser uma planta perene, ideal para fenação e silagem, adaptado a varias regiões do Brasil e boa resposta a adubação nitrogenada. Porem suas desvantagens como plantio por mudas, susceptível ao ataque por cigarrinhas, manejos prolongados e sua exigência em fertilidade pode tornar inviável sua utilização.

-Cynodon nlemfuensis Vanderyst - Grama estrela: O centro de distribuição das gramas estrela (Cynodon nlemfuensis Vanderyst), corresponde a porção leste da África tropical, e a Angola na África Ocidental (Pedreira, 1996), mas foi nos centros de pesquisas dos Estados Unidos (Flórida) que essa cultivar teve seus méritos reconhecidos e difundidos por grande parte do mundo. 
MOUSQUER, C.J. et al. Potencial de utilização de silagem de gramíneas tropicais não convencionais e cana-de-açúcar. PUBVET, Londrina, V. 7, N. 22, Ed. 245, Art. 1622, Novembro, 2013.

A grama estrela (Cynodon nlemfuensis Vanderyst), por ser uma cultivar rústica e de crescimento agressivo, destaca-se como opção em muitos sistemas de produção animal a pasto e também como alimento conservado. Como características pode-se citar algumas que se destacam: perenidade, estolonífera, apresenta colmos eretos, não possui rizomas, porém é bem adaptada a condições de estresse hídrico, enraizando-se nos nós e cobrindo rapidamente o solo. Em solos mais férteis podemos encontrar plantas com colmos medindo 1,2 á 2,7 mm de diâmetro e com alturas de 50 á $80 \mathrm{~cm}$.

Estudos realizados por Ramos et al. (1980 e 1982) avaliaram os efeitos de doses de nitrogênio e intervalos de cortes com a grama estrela (Cynodon nlemfuensis Vanderyst) e observaram produções de matéria seca acima de 25 t/ha/ano.

Diante do potencial de produção da grama estrela, surge a opção do uso como alimento conservado na forma de silagem. O emprego da tecnologia de produção de silagem de gramíneas do gênero Cynodon pode trazer maior flexibilidade ao manejo do campo de produção de feno.

O crescimento não controlado de microrganismos, provocando aquecimento na massa ensilada, pode causar perdas nutricionais e afetar a saúde dos animais. Para minimizar esse tipo de problema, o desenvolvimento de inoculantes cada vez mais específicos para as necessidades das espécies de capins tropicais vem conquistando o mercado e a confiança dos pecuaristas (Bumbieris Junior, 2006). Os aditivos mais utilizados na manipulação da fermentação podem ser compostos por ácidos, sais, carboidratos fermentáveis ou culturas de bactérias láticas, além de enzimas.

Agregar valor a qualidade da silagem seria uma boa definição para a utilização de aditivos, potencializando a ingestão de nutrientes mais facilmente digeridos, favorecendo a utilização de gramíneas com potencial ainda não totalmente explorado para o processo de ensilagem, visando cada vez mais o aperfeiçoamento da pecuária. 
MOUSQUER, C.J. et al. Potencial de utilização de silagem de gramíneas tropicais não convencionais e cana-de-açúcar. PUBVET, Londrina, V. 7, N. 22, Ed. 245, Art. 1622, Novembro, 2013.

A grama estrela (Cynodon nlemfuensis Vanderyst.), tem como uma de suas característica, a rápida cobertura do solo com seus vastos estolões, garantindo proteção do mesmo. Rústica e resistente as condições climáticas adversas, em virtude da formação de raízes nos nós dos estolões, essa gramínea tem sido uma opção interessante não só por essas características, mas também pela elevada produção de forragem.

Por se tratar de uma espécie altamente difundida, principalmente por criadores de animais destinados à produção leiteira, a pesquisa com a grama estrela na forma de silagem torna-se importante. Principalmente do ponto de vista de estar estabelecida em grandes áreas por várias regiões do país, ter potencial produtivo para estimular sua utilização com essa finalidade e apresentar bom valor alimentício (Bumbieris Junior, 2006).

-Brachiaria brizantha (Hochst. ex A. Rich) Stapf. cv. Marandú: O capim Marandu é um ecótipo originário de regiões vulcânicas da África tropical, que durante muitos anos foi cultivado no Brasil, na região do município de Ibirarema, Estado de São Paulo. Em 1977 a Estação de Pesquisas em Pastagens de Marandela - Zimbabwe, na África, enviou amostras do material vegetal ao CNPGC - Centro Nacional de Pesquisa de Gado de Corte, da EMBRAPA - Empresa Brasileira de Pesquisa Agropecuária, localizado no município de Campo Grande, Estado do Mato Grosso do Sul, onde passou a ser estudada sob o código de acesso BRA - 000591. No ano de 1979 o CPAC Centro de Pesquisa Agropecuária do Cerrado, também da EMBRAPA, recebeu parte do material para estudo. No ano de 1984 houve o lançamento oficial do cultivar, numa parceria entre o CPAC e CNPGC, servindo como mais uma alternativa aos pecuaristas brasileiros (Nunes et al. , 1985; Renvoize et al. , 1998) citado por (Silva, 2010).

Forrageira subcespitosa, muito robusta, possui alta capacidade de cobertura do solo, 1,5 a 2,5 m de altura, temperatura ótima na faixa de 30 a $35^{\circ} \mathrm{C}$, sendo mínima de $15^{\circ} \mathrm{C}$, sistema radicular profundo, com colmos iniciais 
MOUSQUER, C.J. et al. Potencial de utilização de silagem de gramíneas tropicais não convencionais e cana-de-açúcar. PUBVET, Londrina, V. 7, N. 22, Ed. 245, Art. 1622, Novembro, 2013.

prostrados, mas que possui perfilhos predominantemente eretos, com rizomas curtos e encurvados. Colmos floríferos eretos, frequentemente com perfilhos nos nós superiores, o que leva à proliferação de inflorescências, especialmente quando a comunidade de plantas é submetida a regime de corte e pastejo, essa espécie possui boa relação folha/colmo.

É uma gramínea perene, de grande produtividade, apresenta boas respostas às aplicações de fertilizantes, tolerância à seca, produz forragem de valor nutritivo satisfatório, apresenta boa tolerância ao frio, permanecendo verde no inverno. Como atributos negativos, podemos mencionar: intolerância a solos com drenagem deficiente e a necessidade de moderada fertilidade para o seu desenvolvimento (Bodgan, 1977) citado por (Silva, 2010).

A época de semeadura, ponto adequado de colheita, tamanho das partículas, compactação e vedação do silo, forma, velocidade e eficiência de enchimento do silo, altura do dossel no momento do corte e uso de aditivos, vão dar as características da silagem conforme a sua qualidade. Na tentativa de elevar a produção de biomassa, muitos produtores aumentam o intervalo entre cortes, ocasionando alterações estruturais e morfológicas do dossel forrageiro. Esse aumento de biomassa tem como principal representante o componente morfológico colmo.

Em estudos realizados por Silva, (2010) comparando a qualidade da ensilagem do capim marandu em diferentes alturas de dossel (30, 45, 60 e 75 $\mathrm{cm})$, constatou que as silagens de gramíneas tropicais possuem menor valor nutritivo quando são colhidas mais tardiamente. Colheitas de forragens com maiores alturas de dossel e, consequentemente, maturidade do material, implicam obtenção de um alimento com baixa relação lâmina foliar/colmo, maior acúmulo de material morto da forragem combinada com a crescente lignificação da parede celular, menor conteúdo celular, baixa proporção de carboidratos solúveis. Isso invariavelmente proporcionará redução na digestibilidade. 
MOUSQUER, C.J. et al. Potencial de utilização de silagem de gramíneas tropicais não convencionais e cana-de-açúcar. PUBVET, Londrina, V. 7, N. 22, Ed. 245, Art. 1622, Novembro, 2013.

O emurchecimento é uma técnica eficiente em elevar o teor de MS das silagens. Em comparação às silagens de capim não-emurchecido, os teores de MS do capim emurchecido aumentaram $97 \%$ no verão e $51 \%$ no inverno. Os valores neste trabalho de Ribeiro et al, (2008), comparando os teores de MS obtidos após o emurchecimento, variaram de 20,4\% (silagem proveniente do capim não-emurchecido, inoculado com $L$. buchneri, no verão) a $85,4 \%$ (silagem produzida com capim emurchecido, inoculado com L. buchneri, no inverno). Porem essa técnica deve ser analisada de forma criteriosa pois, altos teores de MS dificulta o processo de ensilagem e os riscos podem ser agravantes.

Ás características bromatológicas da silagem de capim Marandu, estão em valores médios de MS de 25,9\%; PB de 7,0\%; FDN de 77,7\%; FDA de $51,6 \%$ e DIVMS de $50,7 \%$ (Silva, 2010).

-Panicum maximum cv Tanzânia: Entre as cultivares da espécie Panicum maximum Jacq., o capim tanzânia vem ganhando destaque em razão de sua alta produção de massa verde. Jank et al. (1994) obteve, para o capimtanzânia, uma produção de 133 t/ha/ano de massa verde e uma produção de MS de $33 \mathrm{t} / \mathrm{ha}$.

Os sistemas de pastejo rotacionados são os mais indicados para o estabelecimento do manejo de $P$. maximum. Porém, uma das principais dificuldades da exploração intensiva de pastagens, por meio de pastejo rotacionado, na maior parte do território brasileiro, é a necessidade de ajuste da lotação das pastagens em decorrência das variações climáticas que criam, durante o ano, uma estação de alta e outra de baixa disponibilidade qualitativa e quantitativa de forragem (Ávila., et al 2003).

De acordo com Coan et al. (2005) o capim tanzânia no seu estádio vegetativo (45 dias) apresentam elevada qualidade nutricional, mas possuem alto teor de umidade, associado ao elevado poder tampão (PT) e aos baixos teores de carboidratos solúveis (CHOsol.), fatores que interferem no processo 
MOUSQUER, C.J. et al. Potencial de utilização de silagem de gramíneas tropicais não convencionais e cana-de-açúcar. PUBVET, Londrina, V. 7, N. 22, Ed. 245, Art. 1622, Novembro, 2013.

fermentativo, impedindo o rápido decréscimo do $\mathrm{pH}$ e possibilitando o desenvolvimento de fermentações indesejáveis.

O processo de fermentação é muito complexo, envolvendo variações reações químicas e microbiológicas na massa ensilada, podendo resultar em uma silagem de boa ou de má qualidade. Para que se possa intervir no processo, fornecendo condições para uma boa fermentação, é preciso que se conheça o perfil de fermentação para cada planta utilizada. A silagem do capim-tanzânia adicionada de doses crescentes de diferentes aditivos (polpa cítrica, farelo de trigo, fubá de milho, etc...) com base nos valores de $\mathrm{pH}$ e nitrogênio amoniacal, melhoram as características fermentativas das silagens de capim-tanzânia. As silagens sem aditivos também apresentaram valores de $\mathrm{pH}$ e nitrogênio amoniacal característicos de uma silagem de qualidade satisfatória; no entanto, os aditivos devem ser utilizados com o intuito de prevenir perdas.

Técnicas empregadas para melhorar a fermentação das silagens como o uso do emurchecimento e/ou de aditivos como a polpa cítrica peletizada, que tem sido incluída em muitos estudos com silagens de gramínea, pois, além de ser fonte de nutrientes, fornece carboidratos solúveis, que melhoram a qualidade da fermentação no silo e possui elevada capacidade absorvente (Tavares et al., 2009).

Segundo Nussio et al. (2002), silagens de capim-tanzânia colhido e picado em três tamanhos de partícula, com adição de $10 \%$ de polpa cítrica ou com capim pré-emurchecido, apresentaram redução nas perdas por efluente em relação à silagem controle. O valor nutritivo da ensilagem pode ser caracterizado também pela produção de efluentes, sendo influenciada pelo teor de MS ensilada. Teores de MS próximos de $30 \%$ as perdas por efluentes podem ser pouco significativas, diminuindo as perdas de soluções como componentes nitrogenados, açúcares e minerais, que vão dar as características de alimento de bom valor nutritivo. 
MOUSQUER, C.J. et al. Potencial de utilização de silagem de gramíneas tropicais não convencionais e cana-de-açúcar. PUBVET, Londrina, V. 7, N. 22, Ed. 245, Art. 1622, Novembro, 2013.

-Panicum maximum cv Mombaça: As gramíneas de clima tropical, dentre elas o capim-mombaça, apresentam elevada produção de matéria seca, concentrada no período chuvoso do ano. Isto gera um excedente de forragem, que pode ser aproveitado na forma de silagem, para utilização na época de escassez de alimento. Todavia, estas gramíneas apresentam baixo teor de matéria seca, alto poder-tampão e baixo teor de carboidratos solúveis nos estádios de crescimento em que apresentam bom valor nutritivo, colocando em risco o processo de conservação por meio da ensilagem, devido às possibilidades de surgirem fermentações secundárias (Evangelista et al., 2004).

A idade de rebrotação pode afetar o desenvolvimento das populações microbianas durante a ensilagem, tendo em vista que o baixo teor de umidade e elevada concentração de carboidratos solúveis, são condições necessárias para o desenvolvimento de bactérias láticas. Todavia, com o avanço da idade de rebrotação, há uma redução do teor protéico e aumento da fração fibrosa da planta o que pode comprometer o valor nutritivo da planta (Cândido et al., 2005).

Os capins colhidos e ensilados em estádio avançado de maturidade apresentam baixos coeficientes de digestibilidade dos nutrientes, o que pode resultar em diminuição do desempenho animal.

Ensilagem de gramíneas com baixo teor de carboidratos solúveis favorece as perdas durante o processo de ensilagem e, aliada ao elevado teor de umidade da forrageira, propicia o desenvolvimento de bactérias do gênero Clostridium.

-Silagem de Cana-de-açúcar (Saccharum officinarum, L.): A cana-de-açúcar surge como uma opção vantajosa por se tratar de um alimento rico em carboidratos solúveis, pela elevada produtividade e principalmente, por estar disponível no período da estação seca. Apesar de apresentar reduzido teor de proteína e minerais, pode ter as suas deficiências corrigidas pelo uso de uréia e 
MOUSQUER, C.J. et al. Potencial de utilização de silagem de gramíneas tropicais não convencionais e cana-de-açúcar. PUBVET, Londrina, V. 7, N. 22, Ed. 245, Art. 1622, Novembro, 2013.

mistura mineral (Oliveira, 2007). A cana-de-açúcar se desenvolve em forma de touceira e a parte aérea é formada por colmos, folhas, inflorescências e frutos, e a parte subterrânea por raízes e rizomas (caules subterrâneos, espessados, ricos em reservas, providos de nós e entrenós e de crescimento horizontal).

Como a maioria das poáceas, a cana-de-açúcar é uma planta C4, assim chamada por formar compostos orgânicos com quatro carbonos. Apresenta também maior taxa fotossintética e de eficiência na utilização e resgate de $\mathrm{CO}_{2}$ da atmosfera. A cana-de-açúcar é adaptada às condições de alta luminosidade, altas temperaturas e relativamente escassez de água, já que necessita de grandes quantidades de água para suprir as suas necessidades hídricas, uma vez que somente $30 \%$ de seu peso é representado pela matéria seca e $70 \%$ pela água (dependendo do estádio fenológico).

Sua capacidade em absorver água pelas folhas é maior do que em qualquer poácea e mesmo o orvalho da madrugada e os chuviscos, que não chegam a atingir o solo, são absorvidos por suas folhas.

A utilização da cana-de-açúcar na alimentação animal fora do período de safra, sofre restrições porque a forragem apresenta menor valor nutritivo em virtude do baixo teor de sacarose. Por esse motivo, tem sido grande a demanda de informações sobre a ensilagem de cana-de-açúcar, técnica que permite que grandes áreas sejam cortadas em um curto espaço de tempo, na época em que a cana apresenta seu melhor valor nutritivo. O processo de ensilagem da cana-de-açúcar é igual a ensilagem de outras gramíneas, consiste em cortar a forragem no campo, picá-la em pedaços de 2 a $3 \mathrm{~cm}$, compactá-la e vedar bem o silo.

Entre as forrageiras tropicais, a cana-de-açúcar destaca-se principalmente por sua elevada produtividade (80 a 120 t de matéria verde/ha) e boa qualidade na época seca do ano, contrastando com as demais forrageiras tropicais (Magalhães et al., 2006). Também podendo ser caracterizados aspectos como; Simplicidade operacional para manutenção; Condução da cultura; Facilidade de aquisição de mudas; pico da produção 
MOUSQUER, C.J. et al. Potencial de utilização de silagem de gramíneas tropicais não convencionais e cana-de-açúcar. PUBVET, Londrina, V. 7, N. 22, Ed. 245, Art. 1622, Novembro, 2013.

associado ao fato do melhor valor nutritivo, coincidir com o período de escassez de forragens verdes nos pastos; a manutenção do valor nutritivo por longo espaço de tempo após atingir a sua maturidade (até seis meses); o desenvolvimento de tecnologia para o seu cultivo e aos trabalhos de melhoramento genético intensos e constantes devido à produção de açúcar e álcool.

É facilmente utilizada por pequenas e médias propriedades, pois dispensa altos investimentos com máquinas e implementos agrícolas para manutenção e condução da cultura, e apresenta baixo custo por unidade de matéria seca produzida (Manzano et al., 2004).

Com o intuito de melhorar os padrões de fermentação da silagem de canade-açúcar, diversos tipos de aditivos vêm sendo testados para que a ensilagem de cana-de-açúcar seja uma alternativa viável e rentável. Portanto, é neste cenário que inúmeros aditivos químicos vêm sendo pesquisados com a finalidade de controlar a população de leveduras e de propiciar a redução das perdas decorrentes dos processos fermentativos (Ribeiro et al., 2010).

As principais limitações nutricionais da cana são; baixo teor de proteína (aminoácidos sulfurados são os mais limitantes); baixo teor de lipídeos (gordura); alto teor de carboidratos de rápida fermentação no rúmen e ausência de amido (degradação ruminal mais lenta e precursor de glicose); baixo teor de minerais (principalmente o fósforo); fibra de baixa digestibilidade e baixo consumo de matéria seca (fatores anteriores associados).

Outro aspecto, diz respeito ao perfil qualitativo da cana como volumoso está relacionado principalmente a digestibilidade da fibra e seu conteúdo de açúcar. $\mathrm{Na}$ prática, esse aspecto tem sido negligenciado como se todas as variedades de cana em qualquer tempo de seu desenvolvimento fossem iguais para a produção forrageira. Vários trabalhos mostram que este fator deve ser considerado de modo mais efetivo.

Para assegurar uma melhor distribuição qualitativa durante a seca e reduzir problemas com o florescimento, a Embrapa Gado de Leite recomenda plantar 
MOUSQUER, C.J. et al. Potencial de utilização de silagem de gramíneas tropicais não convencionais e cana-de-açúcar. PUBVET, Londrina, V. 7, N. 22, Ed. 245, Art. 1622, Novembro, 2013.

metade da área com variedades precoce (RB83-5486, RB76-5418, SP80-1842 e IAC86-2210) e a outra com variedades médias ou tardias (CB-45-3, RB72454, SP71-1406, RB73-9743, RB73-9359, SP70-1143 e SP79-1011).

Uma colocação importante é que o mito de ser considerado um volumoso restrito a animais de baixo potencial produtivo, quer seja para a produção de leite ou de carne, preconizado por pesquisadores e técnicos nos anos 70 e 80, vem sendo substancialmente renegado. Encontrava-se na literatura citações taxando a utilização da cana-de-açúcar para vacas com produção até $10 \mathrm{~kg}$ leite/dia ou alimento para atender somente as exigências de mantença, com ganhos marginais em bovinos de corte.

Atualmente, trabalhos de pesquisa e experiências práticas mostram que a cana-de-açúcar pode e deve ser utilizada para animais de alta produção. Os conceitos foram se modificando, e a pecuária passou a entender que este alimento é fonte de energia, ao invés de ser criticado pelo baixo teor de proteína.

Os inoculantes bacterianos e os aditivos químicos, quando adicionados à ensilagem da cana-de-açúcar, isoladamente, tem reduzido o teor de etanol nas silagens, mas de forma moderada. A associação dos inoculantes bacterianos com aditivos químicos é considerada uma estratégia para o controle de leveduras, com conseqüente redução da produção de etanol (Siqueira et al., 2004).

Alcântara et al. (1989) observou que, após 30 dias de ensilagem, para a silagem de cana-de-açúcar sem $\mathrm{NaOH}$ valores de 1,5\% de ácido lático, 0,46\% de ácido acético, $0 \%$ de ácido butírico e 1,45\% de etanol, enquanto na silagem de cana-de-açúcar tratada com $\mathrm{NaOH}$ os valores foram de $2,19 \%$ de ácido lático, $0,66 \%$ de ácido acético, $0 \%$ de ácido butírico e 0,22\% de etanol.

Pedroso (2003), avaliando vários aditivos químicos, observou que aditivos alcalinos, como o hidróxido de sódio, elevam substancialmente os valores de digestibilidade da MS, quando comparado ao tratamento 
MOUSQUER, C.J. et al. Potencial de utilização de silagem de gramíneas tropicais não convencionais e cana-de-açúcar. PUBVET, Londrina, V. 7, N. 22, Ed. 245, Art. 1622, Novembro, 2013.

testemunha 62,5 e 45,4 respectivamente. Também na comparação com o controle, a utilização de Uréia e Benzoato, obteve valor de 49,9 para ambos.

A aplicação de aditivos como a uréia pode melhorar a qualidade de silagens de cana-de-açúcar e diminuir a população de leveduras e mofos, reduzindo a produção de etanol, as perdas de MS e de carboidratos solúveis e proporcionando melhor composição bromatológica em silagens tratadas, em comparação a silagens exclusivamente de cana (Lopes et al., 2007).

Mendes et al., (2008) avaliaram os efeitos do Lactobacillus buchneri na silagem de cana-de-açúcar, e concluíram que a adição de Lactobacillus buchneri melhora a eficiência do processo de ensilagem da cana-de-açúcar, pois reduz as perdas de matéria seca e mantém $\mathrm{opH}$ constante durante $\mathrm{o}$ período de aerobiose, promovendo maior estabilidade aeróbia do material ensilado.

Com relação ao tamanho da área de plantio, devemos ter conhecimentos:

- Valores calculado em função do número de animais que serão tratados;

-O período que se pretende alimentá-los; e

- produção esperada do canavial.

OBS: Como a cana-de-açúcar de primeiro ano é superior a dos anos seguintes, pode-se aumentar a área calculada em $10 \%$.

\section{Aditivos}

Algumas forrageiras tropicais são de difícil ensilagem, porem a utilização de aditivos, visa melhorar a preservação, fermentação e posterior qualidade da silagem.

Os aditivos podem ser divididos em três categorias gerais: estimulantes da fermentação (enzimas e inoculantes bacterianos); inibidores da fermentação (ácidos orgânicos e inorgânicos); e substratos ou fontes de nutrientes (melaço, 
MOUSQUER, C.J. et al. Potencial de utilização de silagem de gramíneas tropicais não convencionais e cana-de-açúcar. PUBVET, Londrina, V. 7, N. 22, Ed. 245, Art. 1622, Novembro, 2013.

polpa cítrica, cama-de-frango, farelo e casca de soja, farelo de algodão, farelo de trigo, fubá de milho, uréia, etc...).

O uso de aditivos absorventes ou sequestrastes de umidade é uma das técnicas mais recomendadas para o controle da produção de efluente em silagens. Alguns aditivos absorventes, além de favorecerem o aumento do teor de MS, proporcionam, também, incrementos na concentração de carboidratos solúveis (Andrade, 2008).

Logo a utilização de aditivos é de estrema importância em silagens de gramíneas tropicais não convencionais e cana-de-açúcar, melhorando a qualidade da mesma e proporcionando a fermentação pelo carboidrato fornecido, prevenindo ou inibindo a fermentação secundaria, favorecendo as condições ideais para microrganismos desejáveis (Lactobacillus) e consequentemente elevando o conteúdo de nutrientes da silagem.

\section{Considerações Finais}

A maior parte das gramíneas tropicais, apesar dos baixos teores de matéria seca e carboidratos fermentescíveis, tem potencial para ensilagem. Entretanto, forragens com maior proporção de folhas devem ser preferidas. As gramíneas tropicais não convencionais e cana-de-açúcar podem ser fornecidas na forma de silagem, porem a adição de inoculantes se faz necessária otimizando o decréscimo de $\mathrm{pH}$ em silagem de capins favorecendo microrganismos desejáveis e reduzindo as fermentações alcoólicas em cana-de-açúcar. Para que o processo como todo seja viável, os cuidados após abertura do silo deve ser enfatizado, visto que os prejuízos serão visíveis no processo de fornecimento ao animal com diminuições na produção de Leite e Carne. 


\section{Referências Bibliográficas}

ALCÂNTARA, E.; AGUILERA, A.; ELLIOTT, R. et al. Fermentation and utilization by lambs of sugarcane harvest fresh and ensiled with and without $\mathrm{NaOH}, 4$. Ruminal kinects. Animal Feed Science and Technology, v.23, n.2, p.323-331, 1989.

ALCÂNTARA, P. B.; BUfARAH, G. Plantas forrageiras: gramíneas e leguminosas 2. ed. São Paulo: Nobel, 1986. 150 p.

ALLI, I.; FAIRBAIRN, R.; BAKER, B. E. et al. The effects of ammonia on the fermentation of chopped sugarcane. Animal Feed Science and Technology, v.9, n.4, p.291-299, 1983.

ANDRADE, I.V.O.; PIRES, A.J.V.; CARVALHO, G.G.P. et al. Fracionamento de proteína e carboidratos em silagens de capim-elefante contendo subprodutos agrícolas. Revista Brasileira de Zootecnia, v.39, n.11, p.2342-2348, 2010.

ANDRADE, I.V.O. Aditivos Vegetais na Ensilagem de Capim-Elefante. Itapetinga-BA: UESB, 2008. 57p. (Dissertação de Mestrado).

ANDRADE, P. Alimentação de bovinos em épocas críticas. In: PEIXOTO, A. M.; MOURA, J. S.; FARIA, V. P. Nutrição de bovinos-conceitos básicos e aplicados, $5^{\circ} \mathrm{ed}$., Piracicaba:FEALQ, 1995, p.239-250.

ÁVILA, C.L.S. Isolamento e uso de Lactobacillus buchner na ensilagem de capimMombaça e cana-de-açúcar. Lavras, MG: UFLA, 2007. 175p. (Tese de Doutorado).

ÁVILA, C.L.S.; PINTO, J.C.; EVANGELISTA, A.R. et al. Perfil de fermentação das silagens de capim-tanzânia com aditivos-teores de nitrogênio amoniacal e pH. Cienc. Agrotec., v.27, n.5, p.1144-1151, 2003.

BOGDAN, A. V. Tropical pasture and fodder crops. New York: Longman, 1977. 475p.

BUMBIERIS JUNIOR, V.H. Valor alimentício de silagens de grama estrela (Cynodon nlemfluenis Vanderyst) com diferentes aditivos. Maringá, PR: UEM, 2006. 91p. (Dissertação de Mestrado).

CÂNDIDO, M. J. D.; GOMIDE, C. A. M.; ALEXANDRINO, E. et al. Marfofisiologia do dossel de Panicum maximum cv. Mombaça sob lotação intermitente com três períodos de descanso. Revista Brasileira de Zootecnia, v.34, n.2, p.338-347, 2005.

COAN, R.M.; VIEIRA, P.F.; SILVEIRA, R.N. et al. Inoculantes enzimáticos-bacteriano, composição química e parâmetros fermentativo das silagens dos capim-tanzânia e Mombaça. Revista Brasileira de Zootecnia, v.34, n.2, p.416-424, 2005.

CRUZ, J. C.; PEREIRA FILHO, I. A. Cultivares de milho para silagem. In: CRUZ, J.C.; PEREIRA FILHO, I.A.; RODRIGUES, J.A.S.et al. (Eds.). Produção e utilização de silagem de milho e sorgo, Sete Lagoas: Embrapa Milho e Sorgo, 2001, p.11-37.

DANNER, H.; HOLZER, M.; MAYRHUBER, E.; BRAUN, R. Acetic Acid Increases Stability of Silage under Aerobic Conditions. Applied and Evironmental Microbiology, Washington, v.69, n.1, p.562-567, 2003. 
DIZ, D. A. Breeding procedures and seed production management in pearl millet $\mathbf{x}$ elephant grass hexaploid hybrids. 1994. 118 p. Tese (Doutorado) - University of Florida, 1994. $118 \mathrm{p}$.

EVANGELISTA, A. R.; PERON, A. J.; AMARAL, P. N. C.; Forrageiras não convencionais para silagem- Mitos e Realidade. In: II Simpósio sobre manejo estratégico da pastagem. 2004, Viçosa, MG. Anais... Viçosa, MG, p.463-508.

EVANGELISTA, A. R. et al. Produção de silagem de capim-marandu (Brachiaria brizantha Stapf cv. Marandu) com e sem emurchecimento. Ciência e Agrotecnologia, Lavras, v.28, n.2, p.443-449, 2004.

FARIA, D.J.G.; GARCIA, R.; TONUCCI, R.G. et al. Produção e composição do efluente da silagem de capim-elefante com casca de café. Revista Brasileira de Zootecnia, v.39, n.3, p.471-478, 2010.

FERREIRA, A.R. Avaliação de aditivos químicos na ensilagem de cana-de-açúcar. Itapetinga-BA: UESB, 2005. 32.p. ( Dissertação de Mestrado).

FERREIRA, J. J. Características qualitativas e produtivas da planta de milho e sorgo para silagem. In: CRUZ, J.C.; PEREIRA FILHO, I.A.; RODRIGUES, J.A.S.et al. (Eds.). Produção e utilização de silagem de milho e sorgo, Sete Lagoas: Embrapa Milho e Sorgo, 2001, p.383 $-404$.

GUIM, A.; ANDRADE, P.; ITURRINO-SCHOCKEN, R. P.; FRANCO, G. L.; RUGGIERI, A. C.; MALHEIROS, E. B. Estabilidade aeróbica de silagens de capim-elefante (Pennisetum purpureum, Schum) Emurchecido e Tratado com Inoculante Microbiano. Revista Brasileira de Zootecnia, v.31, n.6, p.2176-2185, 2002.

IGARASI, M.S. Controle de perdas na ensilagem de capim Tanzânia (Panicum maximum Jacq. cv. Tanzânia) sob os efeitos do teor de matéria seca, do tamanho de partícula, da estação do ano e da presença do inoculante bacteriano. Dissertação de Mestrado - ESALQ/USP, Piracicaba, p. 65, 2002.

JANK, L.; SAVIDAN, Y.; SOUZA, M. T.; COSTA, J. G. C. Avaliação do germoplasma de Panicum maximum introduzido da África: 1 . Produção forrageira. Revista da Sociedade Brasileira de Zootecnia, Viçosa, v. 23, n. 3, p. 433-440, 1994.

LIMA, J.A.; CUNHA, E.A. Silagem: Capricho na retirada é fundamental para colocar no cocho silagem de boa qualidade. 2006. Artigo em Hypertexto. Disponível em: <http://www.infobidos.com/artigos/2006_3/silos/index.htm>. Acessado em: 09/11/2012.

LIMA, J. A.; EVANGELISTA, A. R. Silagem de capim elefante (Pennisetum purpureum Schum). Disponível em <www.forragicultura.br>, Acesso em: 08/08/2012.

LOPES, B. A. O capim elefante, 2004. Seminário apresentado à disciplina ZOO 645 (Métodos nutricionais e alimentação de ruminantes), Disponível em: <http://www.forragicultura.com.br>, Acesso em: 12/12/2012.

LOPES, J.; EVANGELISTA, A.R.; ROCHA, G.P. Valor nutricional da silagem de cana-de-açúcar acrescida de uréia e aditivos absorventes de umidade. Revista Brasileira de Zootecnia, v.36, n.4, p.1155-1161, 2007. 
MAGALHÃES, A. L. R.; CAMPOS, J. M. S.; CABRAL, L. S.; MELLO, R.; FREITAS, J. A. ; TORRES, R. A.; VALADARES FILHO, S. C.; ASSIS, A. J. Cana-de-açúcar em substituição à silagem de milho em dietas para vacas em lactação: parâmetros digestivos e ruminais. Revista Brasileira de Zootecnia, v.35, n.2, p.591-599, 2006.

MANZANO, R. P.; PENATI, M. A.; NUSSIO, L. G. Cana-de-açúcar na alimentação de bovinos. In: Apostila do Curso de Especialização em Produção de Ruminantes Pastagens e Forragens Suplementares, Piracicaba - SP: FEALQ, 2004 (Folheto técnico).

MENDES, C.Q.; SUSIM, I.; NUSSIO, L.G. et al. Efeito do Lactobacillus buchneri na fermentação, estabilidade aeróbica e no valor nutritivo de silagem de cana-de-açúcar. Revista Brasileira de Zootecnia, v.37, n.12, p.2191-2198, 2008.

NASCIMENTO JÚNIOR, D. Informações sobre algumas plantas forrageiras do Brasil. Viçosa, MG: UFV, 1975. 73 p.

NUNES, S. G.; BOOCK, A.; PENTEADO, M. I. O. Brachiaria brizantha cv. Marandu. 2 ed. Campo Grande: EMBRAPA-CNPGC, 1985. 31 p. (Documentos, 21).

NUSSIO, L. G. Efeitos de níveis de concentrado sobre o desempenho de bovinos e digestibilidade de dietas a base de bagaço de cana-de-açúcar (Saccharum sp L.) tratado sob pressão de vapor. 1993. 147p. Dissertação (Mestrado em Zootecnia) - Escola Superior de Agricultura "Luiz de Queiroz", Universidade de São Paulo, Piracicaba, 1993.

NUSSIO, L. G.; PAZIANI, S. F.; NUSSIO, C. M. B. Ensilagem de capins tropicais. In: REUNIÃO ANUAL DA SOCIEDADE BRASILEIRA DE ZOOTECNIA, 39., 2002, Recife. Anais... Recife: Sociedade Brasileira de Zootecnia, 2002. p.60-99.

PEDREIRA, C. G. S. Avaliação de Novas Gramíneas do Gênero Cynodon para a Pecuária dos Estados Unidos. In: Anais do Workshop sobre o Potencial Forrageiro do Gênero Cynodon. Juiz de Fora, 1996. p, 111.

PEDROSO, A.F. Aditivos químicos e microbiano no controle de perdas e na qualidade de silagem de cana-de-açúcar (Sccharum afficinarum L.). Piracicaba- ESALQ, 2003. 120 p. (Tese de Doutorado).

PINA, D. S.; VALADARES FILHO, S. C.; VALADARES, R. F. D. et al. Consumo e digestibilidade aparente total dos nutrientes, produção e composição do leite de vacas alimentadas com dietas contendo diferentes fontes de proteína. Revista Brasileira Zootecnia, v.35, n.4, p.1543-1551, 2006.

PIRES, W. Manual de pastagem: Formação, Manejo e Recuperação. 302p, ed. Aprenda Fácil, 2006, Viçosa, MG.

OCUMPAUGH, W. R.; SOLLENBERGER, L. E. Other grasses for the humid south. In: BARNES, R. F.; MILLER, D. A.; NELSON, C. J. Forages. 5. ed. Iowa: Iowa State University, 1995. v. 1, p. 441-450.

OLIVEIRA, I. S. Avaliação de volumoso na dieta de vacas leiteiras na época seca: Consumo, digestibilidade, produção de leite e simulação do CNCPS. Cuiabá, MT: UFMT, 2007. 83 p. (Dissertação de Mestrado). 
RAMOS, N.; CURBELO, F.; HERRERA, R. S. Edad de rebrote y niveles de nitrógeno em pasto estrela (Cynodon nlenfuensis). 1. Componentes Del rendimiento y eficiência de utilización de nitrógeno. Revista Cubana Ciência Agricola , La Habana, v. 16, n.2, p. 305-312, 1982.

RAMOS, N.; HERRERA, R. S.; CURBELO, F. Edad de rebrote y niveles de nitrógeno em pasto estrela (Cynodon nlenfuensis). Revista Cubana Ciência Agricola , La Habana, v. 14, n.1, p. 83-93, 1980.

REIS, R. A.; GARCIA, R.; SILVA, D.J. Efeito da aplicação de amônia anidra sobre a composição química e digestibilidade de in vitro de fenos de três gramíneas tropicais. Revista da Sociedade Brasileira de Zootecnia, v.19, n.3, p.219-224, 1990.

REIS, R.A.; COAN, R.M. Produção e utilização de silagens de gramíneas. In: III Simpósio goiano sobre manejo e nutrição de bovinos. Anais... Goiânia, GO, p.91-120, 2001.

RENVOIZE, S. A.; CLAYTON, W. D.; SKABUYE, C. H. Morfología, taxonomía y distribución natural de Brachiaria (Trin.) Griseb. In: MILLES, J. W.; MASS, B. L.; VALLE, B. C. (Ed.). Brachiaria: biología, agronomía y mejoramiento. Cali: CIAT; Campo Grande: EMBRAPA CNPGC, 1998. cap. 1, p. 1-15.

REZENDE, V.M. Degradabilidade ruminal das silagens de capim napier produzidas com diferentes níveis de farelo de "batata diversas". Lavras, MG: UFLA, 2005. 52 p. (Dissertação de Mestrado).

RIBEIRO, J.L.; NISSIO, L.G.; MOURÃO, G.B. et al. Valor nutritivo de silagens de capimmarandú submetidos aos efeitos de umidade, inoculação bacteriano e estação do ano. Revista Brasileira de Zootecnia, v.37, n.7, p.1176-1184, 2008.

RIBEIRO, L.S.O.; PIRES, A.J.V.; CARVALHO, G.G.P. et al. Composição química e perdas fermentativas de silagem de cana-de-açúcar tratada com uréia ou hidróxido de sódio. Revista Brasileira de Zootecnia., v.39, n.9, p.1911-1918, 2010.

SANTOS, B.N.R.; SALES, R.O.; COSTA, M.R.G.F. Teores de matéria seca e matéria mineral do feno de duas variedades de capim-elefante sob períodos de corte. Revista Brasileira de nutrição animal, Ceará, UFC, v.1, n.1, p. 26-31, 2007.

SANTOS, E.M. População microbiana e perfil fermentativo em silagens de capins tropicais e desempenho de bovinos de corte alimentados com dietas contendo silagens de capim-mombaça. Viçosa: UFV, 2007. 127p. (Tese de Doutorado).

SANTOS, E. M.; ZANINE, A. M.; OLIVEIRA, J. S. Produção de silagem de gramíneas tropicais, REDVET Revista electrónica de Veterinária, v.VII, n.7, p.1-16, 2006.

SILVA, B.C.; PEREIRA, O.G.; PEREIRA, D.H. et al. Consumo e digestibilidade aparente total dos nutrientes e ganho de peso de bovinos de corte alimentados com silagem de Brachiária brizantha e concentrado em diferentes proporções. Revista Brasileira de Zootecnia, v.34, n.3, p. 1060-1069, 2005.

SILVA, J.B. Qualidade da ensilagem do capim-marandú manejado sob diferentes alturas de dossel. Unimontes, 2010. 112 p. (Dissertação de Mestrado).

SIQUEIRA, G. R.; ITURRINO, R. P. S.; BERNARDES, T. F. et al. Interações entre inoculantes microbianos e aditivos químicos na fermentação e na estabilidade aeróbia de cana de açúcar. In: Reunião da SBZ, 41. Campo Grande, 2004. Anais... Campo Grande: SBZ, Cd-rom 2004. Forr 217. 
SUNDSTOL, F.; COXWORTH, E.; MONTH, D.N. Improving the nutritive value of straw and other low quality forages by treatment with ammonia. World Animal Review, v.26, p.13-22, 1982.

TAVARES, V.B.; PINTO, J.C.; EVANGELISTA, A.R. et al. Efeitos da compactação da inclusão de aditivos absorventes e do emurchecimento na composição bromatologica de silagens de capim-tanzânia. Revista Brasileira de Zootecnia, v.38, n.1, p.40-49, 2009.

VASCONCELOS, W.A.; SANTOS, E.M.; ZANINE, A.M. et al. Valor nutritivo de silagens de capimmombaça (Panicum maximum Jacq.) colhidos em função de idades de rebrotação. Rev. Bras. Saúde Prod. An., v.10, n.4, p.874-884, 2009.

ZANATO, J.A.F. Bagaço de cana-de-açúcar hidrolisado para coelhos em crescimento. Jaboticabal: UNESP, 2008. 79p. (Dissertação de Mestrado). 